\title{
Motivation as a Factor Responsible for Entrepreneurial Growth in Nigeria: A Case Study of Export Logistics Limited, Akure, Nigeria
}

\author{
Zacheus 0. Opafunso \\ Dean, School of Management Technology, Federal \\ University of Technology, Akure, Nigeria \\ E-mail: zopafunso@yahoo.com \\ Omonigho T. Okhankhuele \\ Department of Project Management Technology, Federal \\ University of Technology, Akure, Nigeria \\ E-mail: omotonia2013@gmail.com
}

Doi:10.5901/mjss.2014.v5n4p166

\begin{abstract}
This paper evaluated the motivational factors that facilitate entrepreneurial growth, and the extent to which entrepreneurs' motivation positively affects entrepreneurial growth of Export Logistics Limited, Akure, Nigeria. The study attempted to find answers to research questions by using survey design to collect data from 70 respondents with the aid of a 17-item questionnaire. The respondents comprised of management and staff of Export Logistics Limited, Akure. Data for this study were analyzed using descriptive statistics and non-parametric statistics - chi-square $\left(X^{2}\right)$ was used to test one hypothesis at $5 \%$ significant level. The findings revealed that the respondents were motivated by both monetary and non-monetary incentives. However, they were more motivated by monetary incentives, and there is a positive and significant relationship between entrepreneurs' motivation and entrepreneurial growth. The paper recommended a continuous inclusion of a wellplanned consensus motivational packages for entrepreneurs in government policies and provision of enabling environment by the government through its policy framework and guidelines.
\end{abstract}

Keywords: Motivation, Entrepreneur, Entrepreneurial, Growth, Development, Export, Cocoa

\section{Introduction}

Entrepreneurship has been revealed to be the instrument of economic growth and development. It plays a very substantial role in the total development of every nation. It contributes significantly to export and balance of payment. The current economic meltdown has made competition to become so deep as a result of unexpected variations in the social, technological, economic and political environment which has compelled the business environment to be very unpredictable to the extent that only extremely motivated, brave, ardent, inventive, confident, and greatly skilled entrepreneurs now have the guts to go into entrepreneurship, take advantage of the erratic changes therein, and survive. Entrepreneurship is faced with so many challenges. These challenges include, inadequate capital, deficiency in experience, uneven power supply, stiff competition, failure to separate business investment and personal money, unfavourable government policies, harsh banking policies for securing loans, discourage entrepreneurship. Despite these challenges, several entrepreneurship are still established daily with optimism and strong will to survive. While a few stay alive and thrive in their businesses, a lot of them pack up within a few years. (Aldrich, 1999) agreed that there is high fatality rate of small firms, more than $50 \%$ of new ventures pack up within $5 y e a r s$.

Paulose, (2011) defined an entrepreneur "as a person who has a registered business and employs at least one person". Entrepreneurs are those who partake in different kinds of small and medium scale enterprises. Shane and Venkataraman, (2000) defined entrepreneurship as the process by which "Opportunities to create future goods and services are discovered, evaluated, and exploited", while Bygrave, (1993) described entrepreneurship as "the acquisition, combination, and redeployment of resources to provide new products and services through new organizations to new markets". Entrepreneurship plays a central role in the advancement of every economy including Nigeria. It helps in creating employment, invention, competition, poverty mitigation and national development.

In desperation for survival midst a multifaceted competitive situation, entrepreneurs employ numerous strategies to 
safeguard survival and growth in the business. The situation is compelling entrepreneurs to become perpetually innovative, or become frustrated out of the market. Motivating entrepreneurs in both private and public sectors is a tactical tool for obtaining extreme output and economic growth. Motivation plays a dynamic role in the growth and continuous existence of all entrepreneurship. Incentives - pecuniary and non-pecuniary are spurs for advancement and productivity in any firm. "Motivation is the internal and external factors that stimulate desire and energy in people to be continually interested and committed to a job, role or subject, or to make an effort to attain a goal. It results from the interaction of both conscious and unconscious factors such as the (1) intensity of desire or need (2) incentive or reward value of the goal (3) expectations of the individual and of his or her peers" (BusinessDictionary.com). "Motivation is a psychological feature that arouses an organism to act towards a desired goal and elicits, controls, and sustains certain goal-directed behaviours. It can be considered a driving force, a psychological one that compels or reinforces an action towards a desired goal. It is an inner drive to behave or act in a certain manner." (Wikipedia). It can be referred to as that vigour that prompts an action in the direction of a desired goal. Lack of sufficient motivation is an inhibition to the progress of an entrepreneur. "Motivation is a vehicle for positive thinking and decision making in organizations that have visions of expansion and development" (Enemuo, 2009). The objectives of the study is to evaluate the motivational factors that facilitate entrepreneurial growth, and the extent to which entrepreneurs' motivation positively affects entrepreneurial growth of Export Logistics Limited, Akure, Nigeria.

Export Logistics Ltd, Akure, Nigeria, has contributed immensely to the development of the Nigerian economy. In the year 2000, Export Logistics Ltd Akure was incorporated under companies and allied matters Act 1990 with a share capital of Ten Million $(\mathrm{N} 10,000,000)$. In the year 2004, the company applied to customs management to operate an entrepreneurial business as Export Bonded Warehousing Logistics and the final approval was given in that year. It started business by exporting thirty thousand $(30,000)$ metric tons of processed cocoa beans to the European market in the year 2004. When the Nigeria customs Service reviewed its guidelines on agencies and companies to transact business in the year 2005, the company applied as a corporate responsible citizen and it met the requirements and was given another approval to export cocoa beans through its haulage operations. It started its operation with 30 trailers but now dynamic management has kept the company growing, it stuffs the processed cocoa beans in fumigated jute bags which are loaded in 20 feet containers and exported through Nigeria premier ports to European markets. Equally, in the year 2005, through the Federal Government's policy on Export Expansion Grant (E.E.G) the company seized to be "bonded" because of non-taxation policy on the produce. As a major player and a trail blazer in this field, it has a lot of challenges like any other entrepreneurship in developing countries such as, lack of finance, market competitions, machineries, logistics, cocoa diseases amongst others. It needs resilience to overcome these challenges. Therefore, this study attempts to look at the effect of motivation on the growth of Export Logistics Ltd, Akure, Nigeria.

\section{Statement of the Problem}

Entrepreneurship plays a very essential role in the total development of every nation. In Nigeria entrepreneurship is confronted with so many challenges which include: inadequate capital, lack of experience, fluctuating power supply, tough competition, failure to distinguish business investment from personal money, unfavourable government policies, harsh banking policies for acquiring loans amongst others. Despite these challenges, numerous entrepreneurship are still established daily with optimism and doggedness to survive. While a few survive and prosper in their Businesses, a lot of them close up within a few years. Only highly strong-minded, skillful, inventive, inspired, self-assured, keen, entrepreneurs with sufficient capital survive the business environment. What motivate these entrepreneurs to go into entrepreneurship? What motivational factors facilitate entrepreneurial growth? and to what extent does entrepreneurs' motivation positively affects entrepreneurial growth? The researcher intends to find the answers to these questions, using Export Logistics Limited, Akure, Nigeria as a case study. However, several researches have been carried out on the factors responsible for entrepreneurial growth. While some of the studies related entrepreneurial growth to motivation and favourable economic environment, others related it to factors internal to the entrepreneur. The findings revealed that the respondents were more motivated by monetary incentives, and there is a positive and significant relationship between entrepreneurs' motivation and entrepreneurial growth. 


\title{
3. Previous Research
}

\subsection{What Motivate Entrepreneurs and lead to Entrepreneurial Success and Growth?}

What motivate entrepreneurs into success? Could it be their internal drive, special skills, creativity, innovativeness, personal willpower and zeal to succeed? co-operation of employees earned through motivation or favourable external environment including government policy? Can entrepreneurship growth be ascribed to factors extrinsic or intrinsic to the entrepreneur? Paulose (2011), in his study, discovered that

\begin{abstract}
the interviewees were motivated by several factors as: money, seeing a gap in the market and wanting to fill it, the need for a change, to make a living, to get more flexibility with their time, lowered job satisfaction as an employee, and lowered access to good jobs.
\end{abstract}

Sexton (2001), Smith and Smith, (2000) established personal characteristics as a main reason for entrepreneurial accomplishment. "It is often said that people cannot win a game that they do not play. This statement suggests that success depends on people's willingness to become entrepreneurs" (Shane, Locke and Collins, 2003). Patel (1995) opined that entrepreneur's attitude and psychology is essential for growth as a lot of entrepreneurship problems are entrenched inside the firm instead of outside. Baum and Locke (2004) opined that the higher the entrepreneur's zeal for work, the higher the successive venture progress. Entrepreneurs frequently attain restricted growth due to deficiency in novel resource proficiency or refuse to hire individuals who are proficient with resources (Timmons, 2000).

Baum et al (2001) argued that "entrepreneurship researches' conclusion that personal characteristics are unimportant for venture performance missed important indirect effects and personal characteristics other than traits". Baum et al (2001) acknowledged motivation as having a direct consequence on novel venture performance.

However, Gartner (1989), confirmed that some researchers reached conclusion that "the study of entrepreneur's personal characteristics is a dead-end strategy". Johnson's (1990), Meta-analysis resolved that need for achievement was the most substantial personal characteristic that determines novel venture performance. McClelland, (1965), supports need for achievement. Brockhaus (1980), proposed risk-taking propensity. Sexton and Bowman, (1986) recommended internal Locus of control. Carsrud and Krueger (1995) suggested that "McClelland (1965), Brockhaus (1980) and Sexton and Bowman, (1986)'s suggestions are wrong attributes for empirical study". Smith and Smith (2000) proposed that entrepreneurs' effective efforts to assemble and organize resources are determinants of novel venture accomplishment. (Storey, 1994) concluded that

the growth of small organizations are influenced by three major factors - the background / resource of the entrepreneur, the nature of the firm, and the strategic decisions taken by the owner / manager.

According to Bass and Stogdill (1990), House and Shamir (1993) and Locke, (2000), persistence was recognized constantly as an exemplary entrepreneurship attribute because the business kick off process entails opposition by difficult obstacles to market entry. Hence, the necessary feature of entrepreneurship is the bravery to endure uncertainty. Shane, Locke and Collins (2003), similarly indicated that the likelihood of success at the entrepreneurial procedure is little, and those eager to continue regardless of these chances may be more confident than people discouraged by these odds. They further discussed some of these factors as:

(1)political e.g. (legal restrictions, quality of law enforcement, political stability, and currency stability, (2) market forces (structure of the industry, technology regime, potential barriers to entry, market size, and population demographics) and

(3) resources (e.g. availability of investment capital, labour market including skill availability, transportation infrastructure and complementary technology).

Several researchers admit that these elements need to be controlled to assess the impact of motivation on the entrepreneurial process. In fact business strategy cannot be planned, and effectively carried out without taking cognizance of the competitive environment.

\subsection{How do Entrepreneurs Cope with Challenges?}

To withstand challenges, entrepreneurs must sincerely love their work and doggedly chase their goals in the face of several hurdles they may come across. Therefore, zeal and doggedness seemed most encouraging in respect to 
leadership and entrepreneurship theoretical assistance (Baum and Locke, 2004). Entrepreneurs confront every prospect and difficulty with enthusiasm. Passion and eagerness for work aids entrepreneurs to survive through monetary barriers and other difficulties. Smilor (1997) submitted that zeal is possibly the most perceived component of the entrepreneurial process. Entrepreneurs who are ardent, active, emotive, responsive, full of drive, love, and affection to attain their goals would ordinarily survive the storm. Bass \& Stogdill, (1990), House and Shamir (1993) confirmed that zeal for work is a trait of efficacious business leaders. Zeal is pertinent in the entrepreneurship scenery because it propels entrepreneurs to face utmost uncertainty and lack of resource (Timmons, 2000). Entrepreneurs who clench tenaciously to their goals without giving up, raise their chances of survival at their kick off stage and thrive (Timmons, 2000).

\subsection{The Role of Human Motivation on Entrepreneurship}

Earlier researches have correctly disapproved of an ample of the present experimental research on the function of human motivation in entrepreneurship (Aldrich and Zimmer, 1986, Carroll and Mosakowski, 1987). Aldrich and Zimmer (1986), indicated that entrepreneurial activity "can be conceptualized as a function of opportunity, structures and motivated entrepreneurs with access to resources". In Shane, Locke, and Collins (2003) the researchers pinpointed numerous human motivations that affect the entrepreneurial process. In their contention, "they assumed that human action is the result of both motivational and cognitive factors". "The cognitive factors include: ability, intelligence and skills" (Locke, 2000). Shane, Locke, and Collins (2003),

Also assumed that entrepreneurship is not solely the result of human action, external factors also play a role (e.g. the status of the economy, the availability of venture capital, the actions of competitors, and government regulations). They however stated that environmental factors are field constant but argued that human motivation plays a critical role in the entrepreneurial process.

They further argued that motivational dissimilarities also affect the entrepreneurial process. (Shane and Venkataraman, 2000) claimed that such things as differences across people in their insights of risk and opportunity effect entrepreneurial choice. Most researchers uphold that it is necessary to control these factors in order to measure the influence of motivation on the entrepreneurial process. If the financial performance of a novel firm is depended on the capability of an entrepreneur to form the firm, and the act of formation rest deeply on human motivation, then human motivation is important to entrepreneurship even if motivation has no direct impact on the performance of the newly established firm (Shane, Locke and Collins, 2003).

\section{Theoretical Framework}

The theories upon which this study is based are, incentive and instinct theories of motivation. These theories are appropriate for this study because they both clarify how motivational factors internal and external to the entrepreneur drive them in the direction of goal-oriented behaviour. "According to incentive theory, people are pulled toward behaviors that offer positive incentives and pushed away from behaviors associated with negative incentives. In other words, differences in behavior from one person to another or from one situation to another can be traced to the incentives available and the value a person places on those incentives at the time" (Bernstein, 2011). Incentive theory was developed in the 1940s and 1950s. The theory suggests that people are driven into action by external incentives. "Instinct theory proposes that organisms engage in certain behaviors because they lead to success in terms of natural selection. It casts motivation as essentially intrinsic and biologically based. Migration and mating are examples of instinctually motivated behavior in animal" (Melucci, 2010). According to the instinct theory of motivation, every organism is given birth to with inborn biological predisposition that aids them to survive. This theory proposes that every behaviour is propelled by natural tendency which are inborn and they make people participate spontaneously in a particular pattern of behaviour. Key features of instinct theory comprise: behaviour, perception, and emotion.

\section{Methodology}

Since the broad objective of this study is to examine the effect of motivation as a factor responsible for entrepreneurial growth using Export Logistics Limited, Akure, Nigeria as a case study, the researcher used survey design to elicit data from 3 strata of management staff, comprising of top, middle and lower level of management, and other staff totally 85 in number. The staff were randomly selected, and information was elicited from them with the aid of personal interview and a structured 17-item questionnaire. The questionnaire consisted of two sections A and B. Section A was based on 
personal bio-data about the respondent while section B comprised of questions drawn from respondents to measure the effect of motivation on the growth of Export Logistics Limited, Akure, Nigeria. 85 copies of questionnaire were administered on face-to-face bases. The response rate was $82.35 \%$, meaning 70 questionnaires were returned. Data for this study were analyzed using descriptive statistics and non-parametric statistics - chi-square $\left(X^{2}\right)$ was used to test the two hypotheses posed for the research at $5 \%$ significant level.

\section{Research Questions}

The following are the research questions posed to guide the study.

1. What motivational factors facilitate entrepreneurial growth?

2. To what extent does entrepreneurs' motivation positively affects entrepreneurial growth of Export Logistics Limited, Akure?

\section{Statement of Hypothesis}

H0: There is no positive and significant relationship between entrepreneurs' motivation and entrepreneurial growth.

\section{Data Presentation and Analysis}

In order to answer the 2 research questions posed for this study, data generated from the field were analyzed. The respondents' bio-data was first analyzed for validity purposes. From the 17-item structured questionnaire with closed ended questions, it was discovered that out of 85 copies of the questionnaires administered, 70 copies were returned. Out of the returned copies, $45(64 \%)$ respondents were male, while the remaining $25(36 \%)$ were female. In addition, the ages of the respondents were widely spread. $25(36 \%)$ of them were within the age bracket of 18-30 years, 25(36\%) between 31-45 years, while the remaining 20(28\%) were between 46-60 years. Majority of respondents were B.SC holders - 45(64\%), M.Sc holders were 5(7\%), and 20 (29\%) SSCE holders.

\subsection{Results and Discussion of Findings}

The results of the study were presented in line with the hypothesis formulated.

Table 1: Answer to Research Question 1, Analyzed with Question 8 on the Questionnaire. Please indicate the motivational factor below that facilitates your entrepreneurial growth mostly, by ticking the box beside your choice.

\begin{tabular}{|l|c|c|}
\hline \multicolumn{1}{|c|}{ Preferred Motivational Factors } & No of Respondents & Percentage \\
\hline Availability of Site & 3 & 4.29 \\
\hline Provision of Funds & 36 & 51.42 \\
\hline Regular Power Supply & 15 & 21.43 \\
\hline Subsidization of processing inputs & 8 & 11.43 \\
\hline Tax Relief & 5 & 7.14 \\
\hline Custom Relief & 3 & 4.29 \\
\hline Total & 70 & 100 \\
\hline
\end{tabular}

\subsubsection{Interpretation of Opinion of Respondents}

$36(51.42 \%)$ of respondents agreed that the provision of funds motivate them into the attainment of entrepreneurial growth more than any other motivational factor, followed by regular power supply 15(21.43\%), subsidization of processing inputs $8(11.43 \%)$, tax relief $5(7.14 \%)$, custom relief and availability of site $3(4.29 \%)$, respectively. This result revealed that the respondents were motivated by both monetary and non-monetary incentives. However, they were more motivated by monetary incentives. This findings agreed with Shane, Locke, and Collins (2003)'s study where they assumed that entrepreneurship is not solely the result of human action, external factors also play a role (e.g. the status of the economy, the availability of venture capital, the actions of competitors, and government regulations). Aldrich and Zimmer (1986), also indicated that entrepreneurial activity "can be conceptualized as a function of opportunity, structures and motivated entrepreneurs with access to resources". The revelation from this study is not surprising because in 
Nigeria, a lot of entrepreneurs have no choice but to depend on their personal savings, borrowed money from friends and relatives to run their businesses. It is often difficult for a lot of them to borrow money from banks because the banks demand collateral which entrepreneurs find difficult to meet up with. Therefore, inadequate money to continuously run small, medium and even large scale businesses in Nigeria cripples and even kills businesses before reaching growth stage. Also epileptic power supply, double taxation, high custom duty, high cost of inputs, high cost of land among others. This shows the importance of finance and regular power supply as a motivating factor to the Nigerian entrepreneurs.

Table 2: Answer to research question 2, analyzed with question 9 on the questionnaire. Entrepreneurial growth is positively affected by the extent to which the entrepreneurs are motivated. Please tick the extent to which you agree with this statement in the boxes beside the options below.

\begin{tabular}{|c|c|c|c|c|}
\hline $\mathbf{0}$ & $\mathbf{e}$ & $\mathbf{0 - e}$ & $(\mathbf{0}-\mathbf{e})^{2}$ & $\frac{(\mathbf{o - e})^{2}}{\mathrm{e}}$ \\
\hline 56 & 14 & 42 & 1764 & 126 \\
\hline 12 & 14 & -2 & 4 & 0.29 \\
\hline 2 & 14 & -12 & 144 & 10.29 \\
\hline 0 & 14 & -14 & 196 & 14 \\
\hline 0 & 14 & -14 & 196 & 14 \\
\hline & & & & $\sum 164.58$ \\
\hline
\end{tabular}

HO: There is no positive and significant relationship between entrepreneurs' motivation and entrepreneurial growth.

\subsubsection{Interpretation of Opinion of Respondents}

$56(80 \%)$ of respondents strongly agreed with the statement that entrepreneurial growth is positively affected by the extent to which the entrepreneurs are motivated, 12(17.14\%) agreed, 2(2.86\%) were undecided, $0(0.00 \%)$, disagreed, while $0(0.00 \%)$ strongly disagreed with the statement. This result reveals that entrepreneurs' motivation has a strong and positive effect on entrepreneurial growth. That means, they believe that motivation propels their zeal to work, increases their output and therefore leads to the firm's growth. This findings agree with (Bernstein, 2011) assertion that, "people are pulled towards behaviors that offer positive incentives and pushed away from behaviors associated with negative incentives". It also agrees with (Enemuo, 2009) assertion that "motivation is a vehicle for positive thinking and decision making in organizations that have visions of expansion and development". Baum et al (2001) acknowledged motivation as having a direct consequence on novel venture performance. Shane, Locke, and Collins (2003), however stated that "environmental factors are field constant but argued that human motivation plays a critical role in the entrepreneurial process".

At $5 \%(0.05)$ level of significance, the chi-square table figure for this study was 9.488 while the chi-square calculated value $\left(\mathrm{x}^{2}\right)$ was 164.58 . It can be seen that the chi-square calculated value is greater than the chi-square table figure. Therefore the NULL hypothesis $(\mathrm{Ho})$ which states: there is no positive and significant relationship between entrepreneurs' motivation and entrepreneurial growth was rejected and the alternative hypothesis ( $\mathrm{H} 1)$ accepted. That means, there is a positive and significant relationship between entrepreneurs' motivation and entrepreneurial growth Therefore, without appropriate motivation, growth rate and productivity of any organization would be low.

Personal interview conducted with the management staff of the organization revealed that there was a systematic annual growth rate in exportation of processed cocoa beans, measured by the number of 20 feet containers exported yearly from 2005(6.8\%), 2006(8.9\%), 2007(10.1), and 2008(13.9\%) by Export logistics Ltd Akure. The management attributed this growth to the dynamic motivational packages to workers of the organization in one hand and the 2005 federal government policy on Export Expansion Grant (E.E.G) in the other. Under this grant the organization enjoyed tax holiday. However, there was a stunted growth rate from 2008 (13.9\%) to 2009 (13.1\%) which was as a result of the international market forces of demand and supply in the years in question, and the economic meltdown of the European economy, which made the management reduce some of its incentives such as duty travelling allowances (DTA), meal subsidy and hazardous allowances. In the year 2010 to 2011 the annual growth rate increased by (25.1\%), as a result of the restoration of some of the incentives and the increase in the international market demand by the European nations. The company also enjoys low interest rate on loans taken for the promotion of agriculture. This illustrates the effect 
government policy could have on entrepreneurial growth.

\section{Conclusion}

It can be inferred from the discussion above that motivation, internal and external to the entrepreneur plays a vital role in entrepreneurial growth. There was a positive and significant relationship between entrepreneurs' motivation and the growth of Export Logistics Limited Akure. Inconsistency in the provision of motivational packages by management and other external motivational factors like, lack of government support through its policy framework create an obstruction in the wheel of growth of the small and medium scale enterprises. The Stunted growth rate recorded by Export logistics Ltd Akure, from $2008(13.9 \%)$ to 2009 (13.1\%) can be attributed to inconsistency in the provision of incentives by the management of Export Logistics Limited Akure. Without a consistent provision of good and adequate motivation, infrastructural facilities and enabling environment by the government, no good investor would be attracted to invest in entrepreneurship, which stimulates economic growth and development. A paradigm shift is absolutely necessary in terms of motivation and government policy frame work in other to achieve a consisted growth, increased productivity and above all attain the millennium development goals of empowerment. The paper recommended, provision of enabling environment by the government through its policy framework and guidelines. This may include regular supply of electricity, provision of tax holiday, subsidization of import duties on processing inputs, relaxation of strict loan requirements for entrepreneurs, government standing as guarantor if enterprise cannot payback loan, like in the United States of America, providing legal protection of property right in form of patents, copyrights, trademarks etc. This would help propel entrepreneurial success and impel entrepreneurs into executing their functions and lead to economic advancement and transformation. Agencies that inspire growth of entrepreneurship should be established. These agencies should assist in counselling, and protecting the interest of small businesses, provide information to help commence, manage, provide free training and resources to ambitious entrepreneurs and promote the growth of small businesses worldwide. A well planned unanimous motivation packages for employees must be included in the organizational plan of Export Logistics Limited Akure. This would give employees a sense of belonging and determination to attain higher productivity and success. Provision of training for prospective entrepreneurs on their intended choice of businesses, and business accounting is necessary.

\section{References}

Aldrich, H. E. (1999). Organizations evolving. London: Sage. In J.R Baum and E. A. Locke (2004): The Relationship of Entrepreneurial traits, skill and motivation to subsequent venture growth. USA: copyright by the American Psychological Association. In journal of Applied Psychology. Vol. 89, No. 4, p. 587.

Aldrich, H., and Zimmer, C. (1986). Entrepreneurship through social networks. In D. Sexton, and R. Smilor (Eds.). The art of science of entrepreneurship. Cambridge MA: Ballinger. pp. 3-23.

Bernstein, D. A. (2011). Essentials of psychology. Belmont, CA: Wadsworth. In Education Psychology by Kendra Cherry. About.com (2013). p. 1. file:///C:/Users/tONIA/Downloads/Incentive\%20Theory\%20of\%20Motivation.htm

Bass, B.M., and Stogdill, R.M. (1990). Bass \& Stogdill's handbook of leadership: Theory, research, and managerial implications. New York: Free Press. In J.R Baum and E. A. Locke (2004): The Relationship of Entrepreneurial traits, skill and motivation to subsequent venture growth. USA: copyright by the American Psychological Association. In journal of Applied Psychology. Vol. 89, No. 4, p. 588.

Baum, J.R., Locke, E.A., \& Smith, K.G. (2001). A multidimensional model of venture growth. Academy of Management Journal, pp. 44, 292-303.

Baum, J.R and Locke, E.A. (2004). The Relationship of Entrepreneurial traits, skill and motivation to subsequent venture growth. USA: copyright by the American Psychological Association. In journal of Applied Psychology. Vol. 89, No. 4, pp. 587-598.

Brockhaus, R. H. (1980). Risk-taking propensity of entrepreneurs. Academy of Management Journal, 23. Pp. 509-520.

BusinessDictionary.com - An internet material.

Bygrave, W.D. (1993). Theory building in the entrepreneurship paradigm. Journal of Business Venturing, 8. pp. 255-280.

Carroll, G., and Mosakowski, E. (1987). The career dynamics of self-employment. Administrative Science Quarterly, 32. pp. $570-589$.

Carsrud, A. L. and Krueger, N.F., Jr. (1995). Entrepreneurship and social psychology: Behavioural Technology for the new venture initiation process. In J.A. Katz \& R.H. Brockhaus, Sr. (Eds), advances in entrepreneurship, firm emergence, and growth. Greenwich, CT: JAI Press. pp. 73-96.

Enemuo, A. U. (2009). Entrepreneurship Studies, Theory and Practices. Onitsha, Nigeria: Abbot Books Limited. pp. 39 and 98.

Gartner, W.B. (1989). "Who is an entrepreneur?" is the wrong question. Entrepreneurship Theory and practice, 13. pp. 47-68.

House, R. J. and Shamir, B. (1993). Toward the integration of transformational, charismatic and visionary theories of leadership. In M.Chemers \& R. Ayman (Eds.), leadership theory and research: perspectives and directions. San Diego, CA: Academic Press. 
pp. 81-107.

Johnson, B. (1990). Toward a multidimensional model of entrepreneurship: The case of achievement motivation and the entrepreneur. Entrepreneurship Theory and Practice, 14. pp. 39-54.

Locke, E. A. (2000a). Motivation, cognition and action: an analysis of studies of task goals and knowledge. Applied psychology: An International Review, 49. pp. 408-429.

Locke, E. A. (2000b). The Prime Movers: traits of the great wealth creators. New. York: AMACOM. In J.R Baum and E. A. Locke (2004): The Relationship of Entrepreneurial traits, skill and motivation to subsequent venture growth. USA: copyright by the American Psychological Association. In journal of Applied Psychology. Vol. 89, No. 4, p. 588.

McClelland D. C. (1965). N achievement and entrepreneurship: a Longitudinal Study Journal of Personality and Social Psychology, 1. pp. 389-392.

Melucci, N. (2010). E-Z Psychology. New York: Barron's Educational Series, Inc. In Instinct Theory of Motivation. In Education Psychology by Kendra Cherry. About.com (2013). p. 1. file:///C:/Users/tONIA/Downloads/instinct-theory-of-motivation.htm

Patel, V. G. (1995). The seven Business crises - How to beat them. New Delhi: Tata McGraw-Hill Publishing Company Limited. 218 pp.

Paulose, A. (2011): Motivation to become entrepreneurs: The case of Indian immigrants to New Zealand. A thesis submitted in partial fulfillment of the requirements for the degree of masters of Business, unitec New Zealand. pp. xi, 2-3.

Sexton, D. L. (2001): Wayne Huizenga: Entrepreneur and wealth creator. Academy of Management Executive, 1. pp. 40-48.

Sexton, D. L., and Bowman, N. B. (1986): Validation of a personality index: Comparative psychological characteristics analysis of female entrepreneurs, managers, entrepreneurship students and business students. In R. Ronstadt, J.A. Hornaday, R. Peterson, \& K.H. Vesper (Eds.), Frontiers of entrepreneurship research. Wellesley, MA: Babson College. pp. 40-51.

Shane, S., Locke, E. A., and Collins, C. J. (2003): Entrepreneurial motivation. In Human Resource Management Review 13. pp. 257260, 263-265. www.sciencedirect.com

Shane, S., and Venkataraman, S. (2000): The promise of entrepreneurship as a field of research. Academy of Management Review, 25(1). pp. 217-226.

Smilor, R. W. (1997). Entrepreneurship: reflections on a subversive activity. Journal of Business venturing, 12. pp. 341-346.

Smith, J.K., and Smith, R. L. (2000): Entrepreneurial finance. New York: Wiley. In J.R Baum and E. A. Locke (2004): The Relationship of Entrepreneurial traits, skill and motivation to subsequent venture growth. USA: copyright by the American Psychological Association. In journal of Applied Psychology. Vol. 89, No. 4, p. 587, 589.

Storey, D. J. (1994). Understanding the Small Business Sector. London/Boston: The International Thomson Business Press. 355 pp.

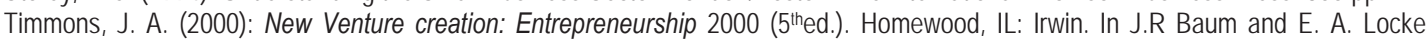
(2004): The Relationship of Entrepreneurial traits, skill and motivation to subsequent venture growth. USA: copyright by the American Psychological Association. In journal of Applied Psychology. Vol. 89, No. 4, p. 588.

Wikipedia - An internet material. 